\title{
The Study of Economic Development Differences of Wonocoyo and Besuki Village Panggul Sub District Trenggalek Regency
}

\author{
$1^{\text {st }}$ Agus Sutedjo \\ Department of Geography, Faculty of \\ Social Sciences and Law \\ Universitas Negeri Surabaya \\ Surabaya, Indonesia \\ agussutedjo@unesa.ac.id
}

\author{
$2^{\text {nd }}$ Bambang Haryanto \\ Department of Geography, Faculty of \\ Social Sciences and Law \\ Universitas Negeri Surabaya \\ Surabaya, Indonesia \\ bambangharyanto@unesa.ac.id
}

\author{
$3^{\text {rd }}$ Sri Murtini \\ Department of Geography, Faculty of \\ Social Sciences and Law \\ Universitas Negeri Surabaya \\ Surabaya, Indonesia \\ srimurtini@unesa.ac.id
}

\begin{abstract}
Jalur Jalan Lintas Selatan (JLS) or South crossroad stripe East Java passes through Wonocoyo and Besuki village, Panggul Sub-district, Trenggalek Regency. JLS is expected to assist the economic development of the area through which it passes. After a few years later, Wonocoyo village is more developed than Besuki village as evidenced by economic activity and higher economic level of the population. This study aimed to know accessibility, infrastructure, resources, and migration in Wonocoyo and Besuki villages. Data about road conditions, the location of economic activities, land use, topography, occupation, education of the population, and population migration was collected. Data obtained was analyzed descriptively and used the connectivity index. The results showed that accessibility, infrastructure, and resources, in Wonocoyo village were better, while the role of a migrant from Wonocoyo village was greater in building the rural economy.
\end{abstract}

Keywords: accessibility, economic development, infrastructure, migration, resources

\section{INTRODUCTION}

Economic development is an important thing for a nation to improve the welfare of its population. The choice of development strategy has important meaning that the expected goal can be achieved. The choice of strategy needs to be based on theories developed and adapted to local conditions. Economic development of a region is affected by many factors, including accessibility, infrastructure, community activities, human resources, natural resources, disaster risk. Each factor is related to other factors and will affect each other. Economic developments will be seen in patterns of settlements, systems, and trend of commodity exchanges, patterns of community movement and migration, and the spreading areas of urban influence, money and information

Accessibility plays important role in the economic development of a region, with the spatial dimension of accessibility being a strategic concept on all models of economic development and has been recognized for its excellence in many areas of economic research [1]. Accessibility can be defined as the convenience of people, materials, or information to move from one location to another, within and between territories. The degree of people, materials, and information movement are critical to the functioning of the regional economy [2]. Physical access and market access are interconnected access to assess the potential of a region. Physical access depends on the existing of infrastructures, such as roadway, railways, airport or seaports. Market access depends on travel distance, travel time, or travel expenses to urban areas, district or provincial capitals, so accessibility is not always related to distance but related to terrain conditions, the degree of transportation or communication tool.

Accessibility will increase if supported by adequate infrastructure, and the role of infrastructure in regional development is important but difficult to determine quantitatively [3]. In regional economic development, four types of infrastructure may be considered, they are powerhouse capacity, roadway, railway, and telecommunication[4]. Accessibility of a region can change with economic development and technological progress, and the level of accessibility will affect the development of regional economy. A common problem that arises in an underdeveloped region is the lack of adequate infrastructure, and it will impact on accessibility levels. In building the infrastructure, the interests of the local population to achieve market access need to be considered. The location where the economic transaction is a market that will connect with other markets by the road network. Assuming that infrastructure will promote economic accessibility, the road network in a region becomes a series of inputs that generate access to markets as output [1].

Roadway construction, both new and extended roads, has a direct and indirect impact on land use. Direct impact means a change from previous land use to the highway, whereas indirect impacts are associated with the development of areas around roadways that require new land for various economic activities. Various researchers have analyzed the impact of road construction on changes in landscape and land cover structures as well as biodiversity and landscapes. It is explained that the construction of road infrastructure will be a driving force in the sustainable development [5].

The positive effect of the interrelationship between urban and rural is the increase of economic activity which impacts on the increase of work and income. In connection with the development of rural transport networks, the number of rural populations affects the formation and sustainability of the periodic country market and its regional 
development. To balance urban and rural development, the direct supply of rural agricultural product and nonagricultural products to these markets should be observed [6].

Natural resources can facilitate the effort to build or improve the economy of a region, especially in the early days of the economic growth process of a region. The beginning of the driving economic growth by using natural resources usually is the agricultural sector. At a later stage will appear many obstacles to develop various economic activities outside the agricultural sector.

A region can develop continually if there is resource internalization, it means the sector that plays as the initial driver can generate or grow other sectors. The agriculture sector as the initial driver of natural resources that can be exhausted because it's not renewable. To be able to develop or generate other sectors, new inputs are needed such as adequate capital, labor, modern production techniques, expert and etc.

The human person is the central subject of development, will act as planners, actors or implementers of activities and at the same time feel the results of its activities. Associated with economic activity, human resource capital becomes an important determinant in regional development and forms the spatial distribution of economic activity [7]. Spatial distribution of the workplace affects the level of wages they will affect the employee welfare level[8].

Population migration is an important issue discussed in the economic development planning of a region. Population structure in a region can change rapidly in the case of migration population that productive aged. This migration may occur due to the condition of the area cannot support their economy. Migration can have a positive or negative impact on the economic development of the region. Negative impacts if the migrating population is an indispensable productive force. In rural communities, there is a strong relationship between age and residence about population motivation to decide to emigrate. Older people will be tied to where they live rather than younger inhabitants. Rural people feel more attached to their natural environment and the spiritual part of their lives, thus unable to emigrate [9].

International migration and remittances have contributed significantly to economic development and improved living standards. International migrant households invest more than others in housing, agriculture, and other companies. Utilization of remittances has also encouraged business diversification and increased investment [10]. Such cases have a positive impact on the territory left by migrants because the economic activities occurred can run on their own capital without dealing with banks that also require a fee. Natural disasters will damage the infrastructure and disrupt the existing community life in an area, this will affect the economic development adversely, so that disaster mitigation needs to be done. Consideration of natural disaster is a priority in regional development so economic development without interruption. Priorities in development related to natural disaster management are high vulnerability areas to natural disasters [11].
One of the factors that can influence the development of a region is concepts related to the ability to move goods and reach other locations efficiently and to the remaining economic conditions associated with population activities [12]. The ability of a region with others are different with respect to regional characters that will never same. This can lead to an imbalance between regions. Imbalance can be inequality between groups, sectoral inequality, or inequality between regions. The imbalance between regions will affect the sustainability of economic growth and regional equity.

Wonocoyo and Besuki villages were originally agricultural areas, located in Panggul Sub-district of Trenggalek Regency, the two villages passed by the Jalur Lintas Selatan (JLS) which is a roadway stripe built in the southern part of East Java. It is a new road completed 10 years ago in order to develop the area in the southern part of East Java that relatively left behind compared to the central and northern parts of East Java. The location of Wonocoyo and Besuki villages is contiguous, but after a decade of JLS functionated the economic development of the two villages is different, now the economic level of the people in Wonocoyo is better than Besuki village. This difference is very important to learn to know the advantages and disadvantages of each village. Furthermore, it can be determined the right strategy for economic development based on the region condition and the existing development concepts. The study of Wonocolo and Besuki villages condition is important to do in order to know the potential of the village for economic development. The objectives of the study were to know: 1) accessibility, 2) infrastructure, 3) resources, and 4) migration in Wonocoyo and Besuki villages.

\section{RESEARCH METHODS}

This study was conducted in Wonocoyo village and Besuki village, Panggul sub-district of Trenggalaek regency, to assess why the two villages are different in their economic level. In this study, the data required was document data taken from various agencies and map analysis results. Data collected include roadway, market locations, occupation and educational level of the population, population migration, land use, topography, natural disasters, and migration. Observations and interviews were also conducted to complete the information. Observations were conducted to determine the condition of roads, market location, land use, topography, while interviews were conducted on several migrant families to find out the use of remittance money. Data obtained to know the level of accessibility was analyzed descriptively and connectivity index by K.J. Kansky was also used in this study. Other data required was the number of economic activity objects and the number of roads that directly connect the object of activity

\section{RESULT AND DISCUSSION}

Infrastructure in Wonocoyo village consists of the roadway, post office, bank, hotel, electricity network, telecommunication, gas station while in Besuki village only roadway, electricity network, and telecommunication. The quantity and quality of infrastructure in Wonocoyo village 
are more and better than Besuki village. The roadway in Wonocoyo village is longer and better quality, as well as the telecommunication network. With such conditions, the people of Wonocoyo village are easier to carry out economic activities, Andres Maroto [1] also explained that infrastructure can improve economic accessibility.

JLS is the main road in Wonocoyo village, beside it there are also a number of narrower roads as an interconnection between settlements, between settlements and public facilities such as public health, school, bank, and market. A number of places of economic activity in Wonocoyo village there is three location that is a shopping complex and two markets are located relatively far apart, while in Desa Besuki only a market. The number of roads connecting directly to the economic activity in Wonocoyo village as many as five roads and four roads in Besuki village. From these data, it can be known that the level of connectivity in Wonocoyo village is 0.6 whereas in Besuki village is 0.25 . This number shows that the level of connectivity in Wonocoyo village is better than Besuki village, the places of economic activity in Wonocoyo village are more easily accessible. This convenience will improve the community in conducting economic activities, people can reach places of economic activity efficiently that impact on the further development of the area [12].

Economic motive is a factor in the migration of people in Wonocoyo and Besuki village because to get a better job and they had no choice in their residences. The types of migration conducted include short-term and long-term migration. Short time migrants who leave their homes less than 6 months, most of them being non-formal workers in urban areas. Long-term migration generally leaves more than 6 months, this type is being a non-formal worker in urban areas or working abroad. The number of migrants between Wonocoyo and Besuki village is balanced but migrants working abroad come more from Wonocoyo village, while from Besuki village they work more in urban areas with shorter durations.

Remittances in Wonocoyo village are used to repair houses, consume daily meals or are used for working capital, whereas in Besuki village it is more widely used for daily food consumption. This can happen because the number of remittances sent to Wonocoyo village is greater. Economic activity in Wonocoyo is more developed than Besuki Village because the use of remittances is more for productive activities. Carrying out mobility means having a role and important meaning in regional economic development, for the less developed area's mobility is a fundamental need and can raise the social status of the family [13].

The education level of the people in Wonocoyo village is $1 \%$ bachelor, $59 \%$ senior high school, $31 \%$ junior high school, $18 \%$ elementary school, and $1 \%$ not in school, while Besuki village is $0.5 \%$ undergraduate, $50 \%$ senior high school , 34\% junior high school, $10 \%$ elementary school and $1 \%$ not in school. The occupation of people in Wonocoyo village includes $56 \%$ farmers, $23 \%$ private or domestic employment, $8 \%$ traders, and $13 \%$ service, while in Besuki village $65 \%$ farmers, $18 \%$ employees (private or domestic), $8 \%$ traders, and $9 \%$ services. Farmers in Wonocoyo village are rice field farmer and field farmer in equal quantities whereas in Besuki village all farmers are field farmer, traders and services cover many types.

Land use in Wonocoyo village consists of $45 \%$ forest and fields, 55\% rice field, and 5\% settlements, while in Besuki village consists of $93 \%$ forest and field, and $7 \%$ settlement. Topography in Wonocoyo village part of a mountain with steep slopes, and sloping slopes of rice fields, while settlements scattered in sloping or slightly sloping slopes in the mountains. In Besuki village most of the mountains with steep slopes, and some of the slopes slightly sloping at the bottom of the mountain slope as a residential area. In Wonocoyo village found two beaches and waterfalls are used for tourism activities.

From the aspect of natural and human resources mentioned above, Wonocoyo village is superior to Besuki village, the population of Wonocoyo village will be better able to utilize the potential of their village to increase economic activity. Especially with the tourist attraction that can be a stronger driver for the development of the region. the population of Besuki village can actually increase economic activity by exploiting the wide potential of forests with a variety of tourist attractions, but certainly, it requires a large enough capital both financial and human resources. Efficient land use that does not damage the ecological system will increase the income of rural areas and communities [14].

From the aspect of disaster, as well as villages in the southern part of Trenggalek regency are of mountains with steep slopes and high rainfall have medium to high risk of landslide disaster. Besuki village has a high risk of landslide disaster because the area is mostly mountains, while Wonocoyo village has a smaller risk of landslide disaster, but on a flat and near the beach, the risk of tsunami waves is very large. The natural disasters occurred will damage the infrastructure and may disrupt the population psychology, therefore different economic development strategies are needed between high risk and lower risk area of natural disasters, priority is given high-risk area and low development levels [11] Besuki village is more prioritized in the development of the region due to the higher potential of disasters and relatively slow economic growth.

\section{CONCLUSION}

According to the results of the study can be concluded that the level of accessibility, infrastructure, natural resources and humans in Wonocoyo village is better than Besuki village, and the role of migrants from Wonocoyo village is also greater in building their village and it impacted on the higher economic level in Wonocoyo village. To improve Besuki village's economy can utilize the advantage of the forest that can be developed with various activities with maintaining the ecological system. And to achieve this, Besuki village needs help from various parties, especially the government because the potential to build a village is relatively small.

\section{ACKNOWLEDGMENT}

This research can be completed with the assistance of FISH UNESA through faculty policy funds in 2017. 


\section{REFERENCES}

[1] J. L. Z. Andres Maroto, “Accessibility gains and road transport infrastructure in Spain: A productivity approach based onMalmquist index," J. Transp. Geografia, vol. 52, pp. 143-152, 2016.

[2] M. Sokol, "Regional Connectivity, International Encyclopedia of Human Geography," in International Encyclopedia of Human Geography, 2009, pp. 165-180.

[3] Roger Vickerman, "Location, accessibility and regional development: the appraisal of trans-European network, Transport Policy," vol. 2, no. 4, pp. 225-234, 1995.

[4] P. YingyingShi, ShenGuo, "The role of infrastructure in China's regional economic growth," J. Asian Econ., vol. 49, pp. 26-41, 2017.

[5] B. P. Stanislaw Bacior, "Infrastructure development and its influence on agriculture land and regional sustainable development," Ecol. Inform., vol. 44, pp. 89-93, 2018.

[6] S. A. Naser Shafiei Sabat, "Urban-rural reciprocal interaction potential to develop weekly marketa and regional development in Iran," Habitat Int., vol. 61, pp. 31-44, 2017.

[7] M. L. Matthias Fluckiger, "Geography, human capital and urbanization: A regional analysis," Econ. Letters, vol. 168, pp. 10-14, 2018.

[8] S. D. David Bogataj, Marija Bogataj, "Interactions between flows of human resources in functional regions and flows of inventories in dynamic processes of global supply chains," Int. J. Prod. Econ., 2017.

[9] Izabela Amalia Mikalca, "The Dynamic of Human Resources in the land of Dorna (Tara Dornelor), Procedia," in Social and Behavioral Sciences 149, 2014, pp. 580-584.

[10] Heinde Haas, "Migration, remittances and regional development in Southern Marocco," Geoforum, vol. 37, no. 4, pp. 565-580, 2006.

[11] N. S. Amin Nurohmah, Anggit Priatmojo, Martha Kurnia Dewi, M. Riski Satria, "Analysis of Regional Development with Multi Disaster Susceptibility in Bengkulu Province," Soc. Behav. Sciences, vol. 135, pp. 70-75, 2014.

[12] D. T. Simone Chaschili, Andrea De Montis, "Accessibility and rurality indicators for regional development," Comput. Environ. Urban Syst., vol. 49, pp. 98-114, 2015.

[13] D. H. John Stanley,Janet Stanley,Camila Balbontin, "Social exclusion: The roles of mobility and bridging social capital in regional Australia," Transportation Resarch Part A: Policy and Practice, 2018. .

[14] X. Z. D. Zhan Wang, Jiancheng Chen, Wentang Zheng, "Dynamic of Landuse effisiency with ecological intercorrelation in regional development," Landcape ang Urban Plan., vol. 177, pp. 303-316, 2018. 